IZA DP No. 10368

Scholarship, the Law and Immigration Policy

Don J. DeVoretz

November 2016 


\title{
Scholarship, the Law and Immigration Policy
}

\author{
Don J. DeVoretz \\ Simon Fraser University \\ and IZA
}

\section{Discussion Paper No. 10368 \\ November 2016}

\author{
IZA \\ P.O. Box 7240 \\ 53072 Bonn \\ Germany \\ Phone: +49-228-3894-0 \\ Fax: +49-228-3894-180 \\ E-mail: iza@iza.org
}

\begin{abstract}
Any opinions expressed here are those of the author(s) and not those of IZA. Research published in this series may include views on policy, but the institute itself takes no institutional policy positions. The IZA research network is committed to the IZA Guiding Principles of Research Integrity.

The Institute for the Study of Labor (IZA) in Bonn is a local and virtual international research center and a place of communication between science, politics and business. IZA is an independent nonprofit organization supported by Deutsche Post Foundation. The center is associated with the University of Bonn and offers a stimulating research environment through its international network, workshops and conferences, data service, project support, research visits and doctoral program. IZA engages in (i) original and internationally competitive research in all fields of labor economics, (ii) development of policy concepts, and (iii) dissemination of research results and concepts to the interested public.
\end{abstract}

IZA Discussion Papers often represent preliminary work and are circulated to encourage discussion. Citation of such a paper should account for its provisional character. A revised version may be available directly from the author. 
IZA Discussion Paper No. 10368

November 2016

\section{ABSTRACT}

\section{Scholarship, the Law and Immigration Policy*}

The legal system has entered the immigration policy framework via class action suits which force immigrant receiving countries to address shortfalls in their immigration and citizenship ascension policies. This paper addresses the role of class action lawsuits in the Canadian context.

JEL Classification: K37

Keywords: immigration policy, class action lawsuits, Canada

Corresponding author:

Don J. DeVoretz

Simon Fraser University

Burnaby, B.C.

Canada

E-mail: devoretz@sfu.ca

* Revised version of a presentation at "Current Themes in Migration Research", The Willi Brandt Guest Professorship 15th Anniversary Symposium, MIM Malmo, 25-26 Jan. 2016. 
$\underline{\text { Introduction }}$

A paradigm shift in the process of blending academic research into the immigration policy process has occurred in North America over the last 3-5 years. Traditionally academic immigration research was largely indifferent to host country immigration policy concerns. However twenty years ago public funds became available to immigrant research academics in North America (Metropolis Project), parts of Europe (MIM in Sweden and IZA in Germany), Israel, the United Kingdom and Australia. These well funded institutes supported academics on the basis of the policy relevance of their topics. Under this migration policy research paradigm independent and peer reviewed research was produced by senior academics and their students to inform policy makers who were in turn charged to make immigration policy decisions hopefully based on the available scientific data. A perfect example of this model was IZA's (Germany) sponsorship of research on the economic impact of immigrant citizenship ascension on the now naturalized immigrant economic outcomes. This fundamental research was conducted in North American and European contexts largely funded by the Volkswagen foundation which allowed an independence from public funds. Given that this extensive research overwhelming reported that a 3-5 year waiting period for citizenship ascension maximized economic gains to immigrants who ascended to citizenship however no country, especially Switzerland and the United States incorporated this outcome in revisions of their respective citizenship acts. In fact, over a wide range of citizenship ascension issues European, North American and Australian academics were repeatedly asked to provide expert testimony based on their research to various political committees on the size, composition and integration issues of the particular country at hand. The transfer of knowledge into the political arena produced little if any dramatic changes in host country immigrant citizenship ascension and integration policies. A cynic could easily draw the conclusion that this publicly funded academic immigrant policy research effort was carefully selected to provide a rasion d'etre for a pre-conceived immigration or citizenship ascension policy.

By 2010 the immigration policy model had changed with the introduction of immigration lawyers. This should not be surprising since many social science academic fields now employ the law and the court system to effect change and bypass politicians and their associated political process. ${ }^{1}$ The challenge under this new academic-legal immigration policy paradigm is to show which issues best fit in this new academic-legal paradigm given that most if not all immigration-legal policy initiatives require funding by third parties namely the immigrants themselves. Often this funding requires that the legal issue at hand will appeal to a large group so that a class action suit funded by immigrants can appear. The aim of this paper is to outline the conditions under which this new legal-academic policy initiative can work given the author's Supreme court experience in Canada and his less dramatic interactions with Canadian law

\footnotetext{
${ }^{1}$ To wit, observe the legal interaction of academic scholars, environmental institutes and dedicated environmental lawyers.
} 
and lawyers to resolve individual cases which would set a legal precedent to effectively change Canadian immigration or citizenship ascension policy.

Immigration Legal Cases: Individual and Class action suits.

Figure 1 depicts the players, the institutions and the process which may lead to immigration litigation under the rule of law.

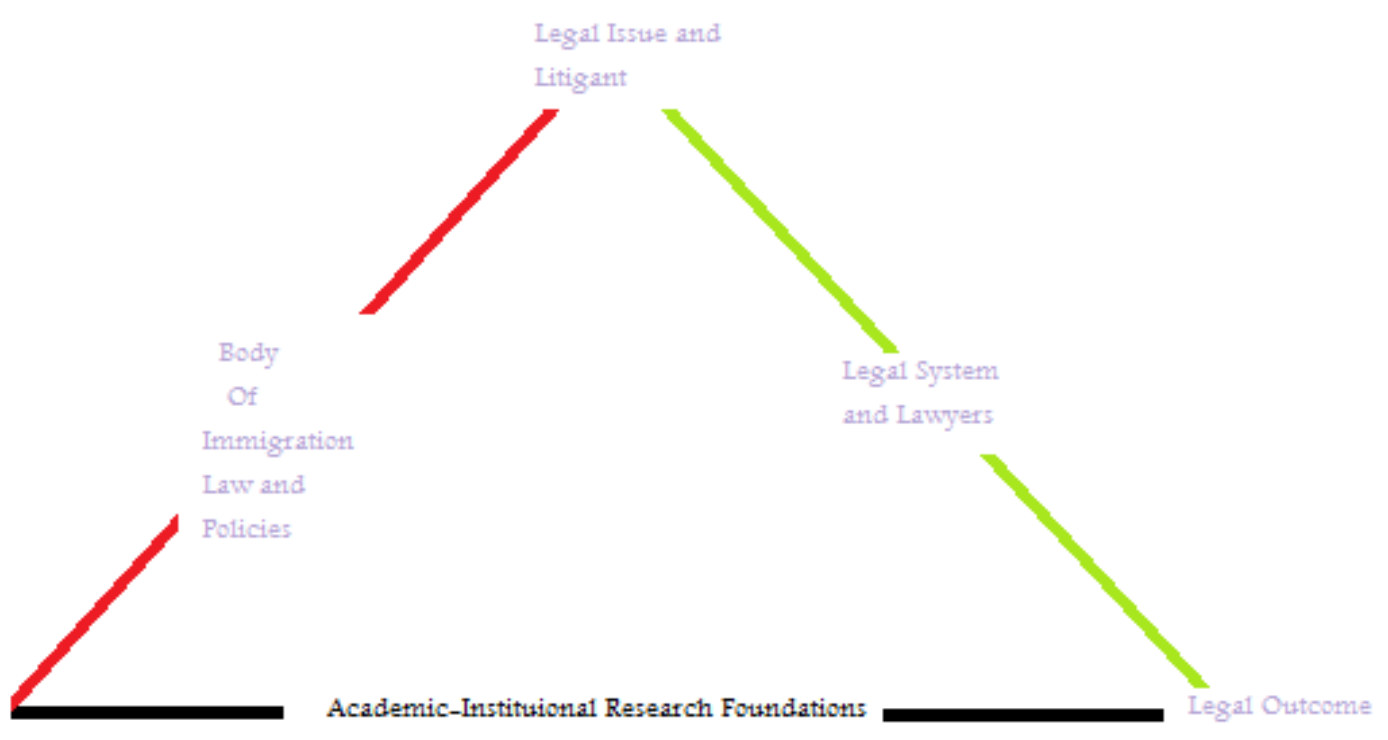

Figure 1 The Legal Immigration Policy Triangle

The base of the triangle (black) represents the body of knowledge developed by individual academics or teams in research foundations. The rest of the triangle rests on this base and the central point of the base is that it provides immigration information to all other actors in the triangle at essentially no cost whether they are a government policy maker, litigant or lawyer. The second part of the triangle (red line) contains the existing immigration law and the resulting policies which presumably when enforced realize the more general principles contained in the country's immigration law. Individual bureaucrats will enforce the policies derived from the country's immigration law and therefore maybe in conflict with a potential immigrant who initially appeals his/her case to the bureaucrat and if unsuccessful may become a litigant. At this point the litigant may appeal the bureaucrat's ruling with the aid of a lawyer (green line)who is familiar with both the immigration issue at hand and the outcomes of any prior litigation to guide the immigrant. 
If the particular immigrant legal issue affects an immigrant group then an individual or a small group of immigrants can form a team which in turn would represent the whole class of immigrants which may be affected by the outcome of this legal dispute. A class action suit has two desirable effects. First, the substantial litigation costs can be potentially spread across a large number of third party immigrant litigants who otherwise could not afford an individual legal action. The second and more important effect is that the decision in a class action suit does not affect just one individual immigrant but by definition a class of immigrants. Given this latter effect the government as a litigant will treat both case and class action litigants with sincerity and due respect. Nevertheless, given the enormous expense of a potential class action suit requires the financial and intellectual support of several participants. First, a legal firm must emerge with both the legal talent and a history in the issue at hand and equally important declares that the litigant's issue at hand qualifies for pro bono status. The declaration of pro bono status has two effects. First the litigants are not responsible for the law firm's expenses. Next, pro bono status confers a halo effect on the legal issue at hand. In other words, the legal issue at hand is deemed so important that existence of a financial barrier or the prospect of a small economic gain can not preclude a hearing in a court of law. It must always be remembered that the state, in this case national governments and their associated immigration policies can be always defended given a near infinite legal budget with no associated time constraints. Many immigrant and citizenship issues live in a finite time world since people and immigrant outcome decisions are more or less important at various stages of life. To wit, delaying parental or spousal immigrant reunification with a third party host country resident is tantamount to denial of immigration rights even if the court ultimately decides in their favour. In short, time and money are important constraints when a legal avenue is taken to resolve an immigrant issue.

What kind of legal firms, individual immigrant litigants and associated expert witnesses emerge in this world of class action immigrant legal contests? Moreover, what type of individual case with no class support emerges to define the principles which ultimately may alter immigration policy?

\section{Individual Litigant Case Study}

I now turn to a typical individual immigrant litigant case to demonstrate both the legal and economic principles in the Canadian context which define an outcome. Each province in Canada has a right to select a relatively small number of individual immigrants under their own set of entry criteria. In a case in British Columbia a 60 year old certified accountant who was being sponsored by his 62 year old brother who in turn was going to employ his 60 year old brother in his British Columbia based accounting firm. The immigrant applicant was denied entry indirectly based on the potential immigrant's age since the provincial government official claimed that his entry would violate "the net benefit criterion". In other words, a provincially selected immigrant had to demonstrate that he/she would pay more taxes than their use of public services over their lifetime whilst resident in British Columbia. The provincial admission officer said the 60 year old applicant would retire at age 65 and would stop paying taxes but would continue to rely on public health and retirement services. The immigrant applicant hired a lawyer who appealed this judgement on the basis of age discrimination and hired me to calculate the potential net present value for a similar cohort already living in British Columbia. Since my calculation demonstrated a positive gain for this applicant's resident cohort his application was eventually allowed 
entry. The ingredients in this successful legal challenge were money to pay for a lawyer and a world class scholar and patience since the applicant waited a total of 18 months for the final decision. However, the reward was larger for society than just the individual's eventually successful application and tax contribution. This case is now a successful precedent for any other similar applicant who is potentially denied entry into British Columbia solely based on age.

Given the numerous immigrant appeals in Canada at both the provincial and federal levels a modified quasi-legal model has emerged to produce results for individual litigants. Legal case study books have emerged which report in detail outcomes by case type. For example, as noted above the principle net economic benefit is invoked as an entry test. Entire books with case studies surrounding this principle are now available for an immigration lawyer or immigrant consultant to research and inform the potential litigant if his/her case has a high probability of success. Given the existence of less expensive immigrant consultants and a free body of case knowledge coupled with the existence of expert and neutral witnesses the engine of growth for changing the application and interpreting the immigrant admission principles has become the now common described legal scenario.

\section{Immigrant Class of Litigants: Two Cases}

A second type of immigrant or citizenship case emerges in which a change in the interpretation of existing legislation itself creates a large and well defined litigant class. Under these circumstances case law does not provide direction for any one individual litigant to challenge (usually) the federal government. In this case where millions of people can be affected by the legal outcome a large law firm will nominate this emerging case for pro bono designation and select a legal team to handle the case. This legal team will in turn contact several neutral expert witnesses to generate new information to support their position. A review of two Canadian cases one real and one potential will offer insight into how fundamental changes can occur in immigration policy through an academic-legal model which ultimately effects millions of Canadians.

xxx versus the Queen involves the loss of voting rights for Canadian citizens who have emigrated abroad. The core of this case is the emergence of a litigant class based on changing interpretations to the Canadian Citizenship Act, the Voting Right Act and Canadian residency. In short, if the Canadian government can demonstrate that a Canadian citizen has lived five or more years abroad that citizen loses the right to vote. The size of the potential litigant pool is 1 million plus Canadian citizens of voting age who live outside of Canada on a permanent basis. The core position of the Canadian government on this ongoing case is that these Canadian citizens have lost their attachment to Canada and hence under a geographically based parliamentary system i.e. ridings, they would lack knowledge of local riding issues. Our two counter arguments contested the concept to two classes of citizens defined by space and the government's contention that physical residence is required for knowledge of local political issues. The case was won in 2014 by the three members of ex patriot Canadian litigant class in the Ontario Superior court. The court agreed that there cannot exist two classes of Canadian citizens and that local knowledge of riding issues is readily available to Canadians living outside of Canada given the internet. As a result of the Ontario Superior Court's favourable ruling for the three litigants, 900,000 Canadian ex-patriot citizens living abroad who were formally resident in Ontario had their voting rights 
restored. A quick appeal by the federal government led to a reversal of the initial finding of the Ontario Supreme Court. Thus, the case will potentially be reviewed by the Canadian Supreme Court. In sum, three litigants, one law firm and three experts all acting on a pro bono basis affected citizenship and voting policies for over 900,000 ex-patriot Canadians.

What Canadian immigrant/citizenship legal issue do I see emerging as a large class issue in the near future? Again it is Canadian federal government actions taken to deny a class of Canadian citizens' fundamental citizenship rights. Until April 2013 Canadian citizenship was granted to all children born in Canada regardless if their parents were Canadian citizens or not (i.e. jus solis). If these children were born outside of Canada to Canadian parents then they were granted Canadian citizenship on the basis of jus sanguinis. In April 2013 the Canadian government revoked the principle of jus sanguinis for the children of those parents who were naturalized Canadian citizens living outside of Canada. In short, two classes of Canadian citizens emerge when they emigrate from Canada. Children born outside of Canada to Canadian-born parents ascend to Canadian citizenship via the principle of jus sanguinis. Children born outside of Canada to naturalized Canadian parents are potentially stateless. What is the potential size of the stateless progeny pool of the children born to naturalized Canadian-born? In short, large. Since the major source countries for Canadian immigrants (China and India) do not recognize the principles of dual citizenship or jus sanguinis children born to naturalized Canadian citizens in their parent's country of birth would often be stateless. ${ }^{2}$

Before I speculate on the possibility of successful class action suit emerging under these conditions let me briefly outline the government's rationale for the suspension of the principle of jus sanguinis for naturalized Canadian parents and their progeny. The suspension of jus sanguinis to the progeny of expatriate naturalized Canadian parents was an indirect policy lever to halt passport shopping or the phenomenon of Hotel Canada. Increasingly the rate of emigration of Asian immigrants to their home country or a developed third country immediately after ascension to Canadian citizenship alarmed Canadian immigration ministers. The evidence is clear that naturalized Chinese and South Asian immigrants to Canada were leaving Canada after gaining Canadian citizenship in their fourth to six year of residence in Canada. What Canadian policy makers envisioned was an infinite stream of Canadian citizens being born abroad who were Canadians who had never lived in Canada. In addition, these second and later generations of Canadian citizens were eligible for a Canadian passport.

The second driving force for the suspension of jus sanguinis to the progeny of expatriate naturalized Canadian parents was an attempt to create a huge disincentive to naturalized Canadians to work outside Canada during their working lives and then return to Canada upon retirement or for medical needs. Of course these naturalized Canadians could return to Canada for the birthing of their children on Canadian soil since the policy of jus solis would entitle their progeny to Canadian citizenship. However, a large tax would be imposed on these naturalized Canadian parents since they would not be covered by Canadian public health insurance unless they lived in Canada for at least six months prior to the birth.

\footnotetext{
${ }^{2}$ Of course many third countries such as the United States recognize the jus solis principle hence a child born there to naturalized Canadian parents would be granted United States citizenship. But the principle of jus solis in the Canadian emigrant's host country is the exception and not a general rule.
} 
How does this analysis of the rationale to suspend jus sangunis to naturalized emigrant parents inform us of the legal issues involved in a class action suit? First the principle of one class of Canadian citizenship is again denied a right all other Canadian citizens have. Second, the denial of Canadian citizenship to the progeny of naturalized Canadian émigrés penalizes these children for actions they did not take, namely their parents emigrating from Canada. Finally, there exists a potential pool of third party litigants, namely the Canadian resident grandparents whose grandchildren are denied access to visit their Canadian resident grandparents.

In sum, the preconditions for a class action suit exist given the potential size of the litigant class, the denial of citizenship rights to one class of Canadian citizens and the hardship endured by either the parents or progeny to circumvent the suspension of the principle of jus sanguinis. The core question is why has not a litigant class emerged to induce a national law firm to take this case on a pro bono basis? First, the case would be politically unpopular. The concept of "Hotel Canada" is embedded in the minds of both Canadian-born residents of Canada and naturalized Canadians in Canada. Thus, immigration policies which penalize perceived Canadian passport of convenience émigrés are favoured by many. ${ }^{3}$ Secondly, a non legal remedy exists to the suspension of jus sanguinis namely, return to Canada for the birth and simply pay the costs. This latter solution could be a strong counter argument of second class citizenship treatment of potential naturalized Canadians émigré parents.

\section{Immigrant Class Discrimination by entry Class}

There exist several entry gates for potential Canadian immigrants. Each gate uses a different set of entry criteria to achieve the gate's presumed goal. However, there also exist universal criteria for immigrant applicant rejection which applies across all entry gates. For example, the potential immigrant's health status, or presumption of the immigrant applicant's security risk will apply as a selection criterion regardless of what entry gate the immigrant choose to be assessed under. The legal problem emerges when the universal selection (rejection) criterion varies across entry gates. Two recent examples will help define the litigious nature of this presumed discrimination.

Canada has a very successful temporary worker immigrant gateway which often leads to permanent residence status after a two to three year period of temporary worker status. In particular temporary foreign workers who work as family workers are allowed to gain permanent residence status after three years of work in Canada. In turn, the gained permanent status allows the erstwhile temporary foreign worker to sponsor his/her minor children. Nonetheless, these temporary foreign workers upon gaining permanent residence status have been denied to the right to sponsor they minor children because the child has a physical handicap. Canadian immigration officials have been quick to deny that the exclusion of the child is not owing to their perceived physical handicap but rather the exclusion of the child is based on a public finance question. In short, if this sponsored child is expected to use 1.6 times the medical coverage of an average Canadian-born child this is grounds for suspending the sponsorship. A recent British Columbia Supreme Court decision reversed the decision to deny entry to a disabled

\footnotetext{
${ }^{3} \mathrm{~A}$ poll in 2011 indicated that resident Canadian citizens strongly disapproved of recent naturalized Canadians leaving Canada on a permanent basis without paying taxes whilst using a Canadian passport.
} 
temporary foreign worker's minor child on the basis that the parent had fulfilled the conditions of the temporary workers admission contract. However, this reversal took two years to obtain and a great deal of time, legal effort and money. The question is will the principle of excessive medical use be allowed to prevent handicap progeny of other permanent residents to enter Canada.

A second recent example of temporary foreign workers using the legal system to protect their workers' rights under the temporary foreign workers programme involves a national company's (i.e.Tim Horton's) treatment of these workers. In short, these temporary workers claim their employer did not abide by British Columbia labour laws when they denied these workers overtime pay, gave them less desirable shifts and most importantly threatened to send them back to their country of origin, i.e. the Philippines. The worker's claim that these actions amount to discrimination by race, ancestry and place of origin. It is interesting to note that these allegations are being made to the $B C$ Human Rights tribunal and not the $\mathrm{BC}$ provincial court. As a consequence only fines can be imposed on the employer and no action can be taken on the Canadian government who created the temporary foreign workers problem.

In sum, these two new cases involving the temporary foreign worker program extends both the breath of the immigration legislation under legal scrutiny and the class of immigrant litigants.

\section{Conclusions}

In 2015 in the Canadian context Canadian immigrants, emigrants and temporary foreign workers have begun to challenge the authority of those who interpret the Canadian immigration and citizenship laws to their detriment. Will this legal process of altering immigrant and citizenship policy widen in Canada or across countries with a strong legal tradition? As an economist the size and scope of this legislation by litigation requires an environment of low legal costs (pro bono) status, expert knowledge at zero costs and a large class of potential litigants. 